\title{
A MULTIMODEL DISCOURSE ANALYSIS OF PERSUASION IN AMERICAN AND ARABIC POLITICAL SPEECHES
}

\section{Prof. Qasim Abbas Dhayef Ph.D ${ }^{1}$}

Hussein Hamid Kareem²

\footnotetext{
${ }^{1}$ Department of English, College of Education for Human Sciences, University of Babylon, Iraq

Email: qasimabbas@uobabylon.edu.iq

${ }^{2}$ University of Babylon, Iraq
}

HNSJ, 2022, 3(1); https://doi.org/10.53796/hnsj3112

Published at 01/01/2022

Accepted at 13/12/2021

\begin{abstract}
This study is based on a critical discourse analysis (CDA) of persuasion in American and Arabic political speeches. It aims to identify how persuasion can be achieved politically as a linguistic device in American and Arabic political speeches. It shows that politicians use manipulation and ideology in order to affect people's decision towards achieving something. Such a thing can be done verbally throughout applying certain discursive strategies or visually throughout posting photographs to depict a certain social situation that reveals a political value. It is hypothesized that American figures have a more dominant role in persuading people than those of the Arabic ones.

To achieve this study, an eclectic model is adapted. It consists of Van Dijk's Discourse and Manipulation (2006) and Barthes's Model of Visual Semiotics (1977). The findings of this study show that the language used is modified in order to attain certain aims and sustain the country's policies. The verbal and visual messages are sent by politicians to persuade others linguistically about something previously intended.
\end{abstract}

Key Words: multimodality, CDA, persuasion, politics, ideology, power, and manipulation. 


\section{Introduction}

One of the fundamental interests of human beings since the beginning of time has been to grow and develop their language so that they can interact with one another without difficulty. Language is the profound way by which life can progress smoothly, as it actively contributes to the success of ordinary social relationships. Its functions, of course, include greetings, requests, information, debating, persuasion, and so on. People, by nature, and even as infants, seek to capture the attention of others, possibly because it is one way to meet their needs. Clearly, persuasion as a tactic for getting people to do what you want is intertwined with this (Batstone, 1995).

A language user can get what he wants from the people he communicates with. This might be accomplished by persuading people, much how it is done in political speeches. Researchers have conducted a large number of studies in an attempt to extrapolate this human special gift due to the fascinating way in which people communicate. In this regard, CDA is quite important, as it is, broadly speaking, given the meaning of language use investigation. CDA refers to the study of the meanings speakers convey and the behaviours they take when communicating in a specific setting. A political speaker may attempt to persuade his audience to believe in something they previously did not believe in. From this perspective, certain discourses succeed in achieving this goal, while others fail spectacularly(Blommaert, 2005).

What's actually important is that some political discourses, or sections of them, have this problem of not achieving what has to be achieved, which requires more attention. The persuasion of a political speech appears to be highly dependent on how it is constructed. In light of this, the problem that prompted us to conduct this study was to identify how to achieve persuasive goals linguistically, because good speakers are capable of implanting their thoughts in the brains of others. So, this study aims to identify how persuasion can be achieved politically as a linguistic device in American and Arabic political speeches.

\section{1. Multimodality}

Brown and Yule (1983) show that in general, it is the employment of more than one mode in meaning-making, communication, and representation. All types of vocal, nonverbal, and contextual communication fall within this category. Multimodality is an inter-disciplinary method to communication and representation that considers communication and representation to be more than just a matter of language.

It has been developed during the last ten years to comprehensively examine hotly disputed concerns about societal developments, such as new media and technologies. Multimodal techniques have provided concepts, tools, and a framework for capturing and analyzing visual, auditory, bodily, and spatial components of interaction and environments, as well as their interactions (Fischer, 1994).

Multimodality adopts that representation and communication employ a variety of modes, each of which contributes to meaning. It focuses on analyzing and describing the full repertoire of meaning-making resources that people use in different contexts (visual, spoken, gestural, written, three-dimensional, and others, basing on the 
area of representation), as well as developing tools to show how these are organized to make meaning (Batstone, 1995).

Dewing (2012) show that multimodality posits that resources are socially changed over time to be meaning-making resources that articulate the (social, individual/affective) meanings requested by various communities' needs. Modes are ordered sets of semiotic resources for producing meaning that realize communicative labor in different ways, making mode selection a key part of interaction and meaning. The more a collection of resources has been used in a community's social life, the more thoroughly and finely expressed it will become. Something must have a shared cultural sense within a community of resources in order to be considered a mode (Fowler, 1991).

Mode, semiotic resource, modal affordance, and inter-semiotic interactions are four basic principles that run across multimodal research. A mode is defined in social semiotics as the result of a material's cultural moulding through its use in people's daily social interactions. The connection between representational resources and what people do with them can be conceived of as the semiotic resources of a mode displaying regularities through the ways in which people use them. These four ideas serve as the foundation for multimodal analysis(Dahl, 1957).

\subsection{Critical Discourse Analysis}

A critical discourse analysis (CDA) is a relatively recent branch of linguistic research that focuses on the relationship between discursive and social activities. It all started in the late 1980s and has rapidly evolved over the following 30 years to become one of the most important approaches to discourse analysis and the social sciences in general (Gumperz, 1982).

CDA has also had an important role in the development of other social scientific and humanitarian fields, such as critical psychology, critical anthropology, and sociolinguistics, some of which date back to the 1970s(Howarth, 2000). CDA is concerned not just with characterizing language and formal linguistic aspects, but also with the interaction of language, society, and ideology. As a result, notions like discourse, power, and ideology are at the heart of CDA research, as they explain how language functions in social situations and how power and hegemony work in society(Batstone, 1995).

In fact, the term 'discourse' has a variety of meanings that are dependent on two factors: first, the researchers themselves, and second, the academic culture. In Central Europe and Germany, for example, the terms 'text' and 'discourse' are distinguished, whereas in English-speaking communities, 'discourse' refers to both written and spoken texts (Dahl, 1957).

The structuralists seem uncomfortable with the concept of discourse as "everything beyond the sentence." They claim that discourse is "language above the clause," emphasizing textual structural features(Mills , 1997).As a result, any social links with discourse are ignored. The functionalists, on the other hand, consider discourse as inextricably linked to the social relations that language facilitates, 
indicating that any study of language must also include a study of its functions in everyday life (Blommaert, 2005).

However, Fairclough (1989) observes that defining 'discourse' is difficult due to overlapping definitions and the fact that it applies to both written and spoken examples of language. He goes on to say that each social circumstance has its own sort of discourse, such as "newspaper discourse," "advertising discourse," and "medical discourse," among others. Nonetheless, discourse has three primary aspects: first, it is "anything beyond the sentence," second, it relates to "language usage," and third, it represents "a broader range of social activity that encompasses nonlinguistic and nonspecific examples of language."

Discourses are used by influential (elite) individuals in a society, such as politicians, the media, and dominant organizations, to infer their ideology and affect the minds of the less powerful groups by using certain linguistic items . As a result, CD analysts strive to uncover ideological components (such as inequality, injustice, hegemony, and so on) that may be hidden beneath any sort of discourse and show them to the less powerful(Brown \& Yule 1983).

CDA is described by Wang (2010: 254) as a form of discourse analysis approach. The goal of CDA is to discover the relationship between language, power, and ideology through public speech, such as political speech. The development of CDA and its orientations has been greatly aided by three techniques. They are: "Fairclough's three Dimensional Approach: Socio - Cultural Approach (1989...1999), Wodak's Discourse - Historical Approach (1995...1999), and Van Djik's SocioCognitive

Approach (1988...2000)".

Discourses can be viewed as direct tools for making sense in a culture where a version of social reality is constructed. Discourses are created for a variety of reasons, one of which is to persuade people through the social context in which they exist. It's also a make-believe reality. Language is the primary tool for creating knowledge and meaning in discourses, but it is not the only one. Language, according to most analysts, is at the heart of discourse theory, which describes how people's understanding of the social world around them is effectively created(Dahl, 1957).

\subsection{Persuasion}

The process by which other people's messages impact a person's attitudes or behavior without coercion. Other elements (for example, verbal threats, physical coercion, and physiological conditions) influence one's attitudes and behavior. Not all communication is meant to persuade; it can also be used to inform or entertain (Dewing, 2012).

Persuasion frequently entails individuals being manipulated, which is why many people dislike it. Others could claim that the human community becomes disorderly without some form of social control and mutual accommodation, such as persuasion. When the alternatives are taken into account, persuasion increases moral acceptability. Persuasion is a means of social control that represents a form of administration (Blommaert, 2005). 
Persuasion was one of the basic liberal arts that any educated man should be able to master; it was elevated to a fine art by preachers who used the spoken word to stimulate any number of actions, such as righteous behaviour or pious pilgrimages, from the time of imperial Rome through the Reformation. Advertising accompanied with speech is the most apparent kind of persuasion in today's world(Brown \& Yule, 1983).

One's response to persuasive communication is influenced by the message and, to a large extent, by how one perceives or interprets it. If words in a newspaper advertisement are printed in red rather than black, they may have different persuasive properties(O'keeffe, 2006). Persuasion, according to perceptual theorists, is defined as changing a person's view of any object of his attitudes. Perceptual techniques are also based on evidence showing the receiver's assumptions are at least as crucial in influencing what will be interpreted as the message content. The method emphasizes focus and comprehension (Dahl, 1957).

Politics, judicial judgments, mass media, news, and advertising are all influenced by persuasion and, in turn, influence us. We want to think we're resistant to persuade. That we have a natural ability to see through sales pitches, understand the truth in a situation, and come to our own conclusions(Fairclough, 1989).

Persuasive messaging can use reasoning or emotions to persuade people. Negative persuasive arguments depict the negative consequences of people failing to pursue a specific course of action or doing the incorrect thing. Positive persuasive messages, on the other hand, emphasize the positive outcomes that can occur if people take a certain course of action or take the incorrect road.

\subsection{Politics}

Politics is the collection of activities related with group decision-making or other forms of power relations between individuals, such as resource distribution or status. Political science is a sub-discipline of social science that analyzes politics and government. It can be used constructively in the context of a compromise and nonviolent "political solution." (Eagleton, 1994). Different methods have fundamentally differing ideas on whether the term should be utilized widely or narrowly, empirically or normatively, and if conflict or cooperation are more important to it(Dewing, 2012).

In politics, a range of approaches are used, including publicizing one's own political beliefs, negotiating with other political subjects, passing legislation, and using force, including warfare against rivals(Osborn \& Osborn, 1988).Politics is practiced on a wide range of social levels, from traditional societies' clans and tribes through modern municipal governments, businesses, and organizations, all the way up to sovereign nations and the international level. People often form political parties to reflect their ideals in modern nation states. Members of a political party frequently agree to have the same stance on numerous topics and to support the same legislative reforms and leaders(Eagleton, 1994).

Power structures and ideologies go hand in hand. Politicians are interested in acquiring power. What they do with that authority depends on their ideology and the 
social, economic, and political realities of the period. It's true that the two are inextricably linked. Even individuals who claim not to have an ideology are subject to this. Power is always used within an ideological framework. The big ideological movements, such as conservatism, liberalism, socialism, fascism, and so on, are the only way to understand modern politics properly(Schwarzmantel, 2008).

The study of the relationship between language and politics is known as linguistic politics. Language is employed to create a state and is implemented in a variety of ways to achieve political goals. Language enables a huge number of individuals to communicate with one other on a broad scale, resulting in the formation of a state. Because language is the foundation of communication, it has an impact on politics. A politician would meticulously construct their manifesto in order to persuade the reader of their legitimacy, in order for the public to have positive feelings about their party. These political parties will then be a part of a structure of linguistic persuasion between the state and the governed, which will aid them in influencing public opinion and power. As a result, political linguistics is a persuasion tool in politics, particularly in speeches and campaigns. When studying political linguistics, one can look at how slogans, mass media, debates, and propaganda can influence people's values and identities(Stubbs, 1983).

\subsubsection{Political speeches}

Politics is a struggle for power and the development of political, economic, and social ideas with the goal of putting them into practice. Every political action is prepared, implemented, or practiced by language, therefore it plays an important role in this process (Fairclough, 1989).political speech is primarily concerned with influencing the public to perform specific political acts or make important political decisions. Thus, propagandists in politics utilize political language to persuade individuals to embrace specific political or social beliefs in order to gain support for a current policy(Stubbs, 1983).

Political studies, according to Chilton (2004:4), emphasize the notion that microlevel behaviors such as threat and persuasion are fundamentally types of language action, i.e. discourse. Similarly, macro-level institutions, such as legislative debates or interviews, are kinds of discourse with distinct characteristics. Political discourse is a branch of discourse and it is founded on two criteria: functional and thematic (Blommaert, 2005).

Political speech is sometimes viewed as an attempt to persuade individuals to switch sides. As a result, persuasion is a prominent characteristic and project of political speech (Fairclough, 1989). 


\section{Methodology}

\subsection{Introduction}

This section deals with the structure that will be followed in analyzing the data. It also shows the source of the data and what model that will be used.

\subsection{Data collection}

Data will be collected from political speeches published the official websites. The data collected is based on the political speeches between 2015 and 2021 to ensure updated data. The data depends on two prominent political figures. The American figure is the USA president called Donald Trump and the Arabic one in Mustafa AlKadhimi. They were chosen in particular since they have their own social and ideological power because of their official status so that the 'persuasion' can be clear in their speeches.

\subsection{Model adapted}

An eclectic model is adapted to achieve this study. It consists of two different models in order to attain objective results. The first model is Van Dijk's Discourse and Manipulation (2006) . It is used to analyze positive self-presentation and negative other-presentation linguistic techniques, as well as to investigate the ideological suppositions that underpin political statements. This model is appropriate for analyzing research data since it necessitates ideology and manipulation, both of which are critical in CDA. Ideology and Manipulation are both mental manipulations that take place in the minds of the listeners and readers. Ideology and manipulation, according to Van Dijk (2006), are the result of power use. Van Dijk offers a set of strategies that can be used at all levels of linguistic analysis. Speakers will employ linguistic terms to deliver a specific message throughout their political speeches. This message can be retrieved by analyzing political speeches using a variety of linguistic methodologies proposed by Van Dijk. Two unique features can be found in political speeches. The in-group and out-group are the two groups. The in-group refers to the habits and acts that politicians emphasize in their speeches in order to persuade people to do them, such as getting people to vote in order to improve their lives.

Things that speakers downplay in order to urge others to avoid them are referred to as the out-group. This is accomplished verbally by the application of various language methods. Such a thing can be done through strategies such as actor description, implication, categorization, self-glorification, number game, evidentiality, and many others.

The second model is Barthes's Model of Visual Semiotics (1977). He proposed the model of significant and signifie to form signs which are viewed ideological images to raise denotative and connotative meaning. Barthes believes that the meaning can be understood indirectly from the signs. According to Roland Barthes, ideological themes are primarily communicated through the use of both words and visuals. The image maintains communicative priority. The image no longer displays the words, but the words that are parasitic on the image structurally. As a result, any linguistic text that appears alongside an image or photos should not be read on its own. Its meaning is derived from the image (Barthes, 1977). . 
Fig.1 An adapted model of Van Dijk's Discourse and Manipulation (2006 ) and Barthes's Model of Visual Semiotics (1977).

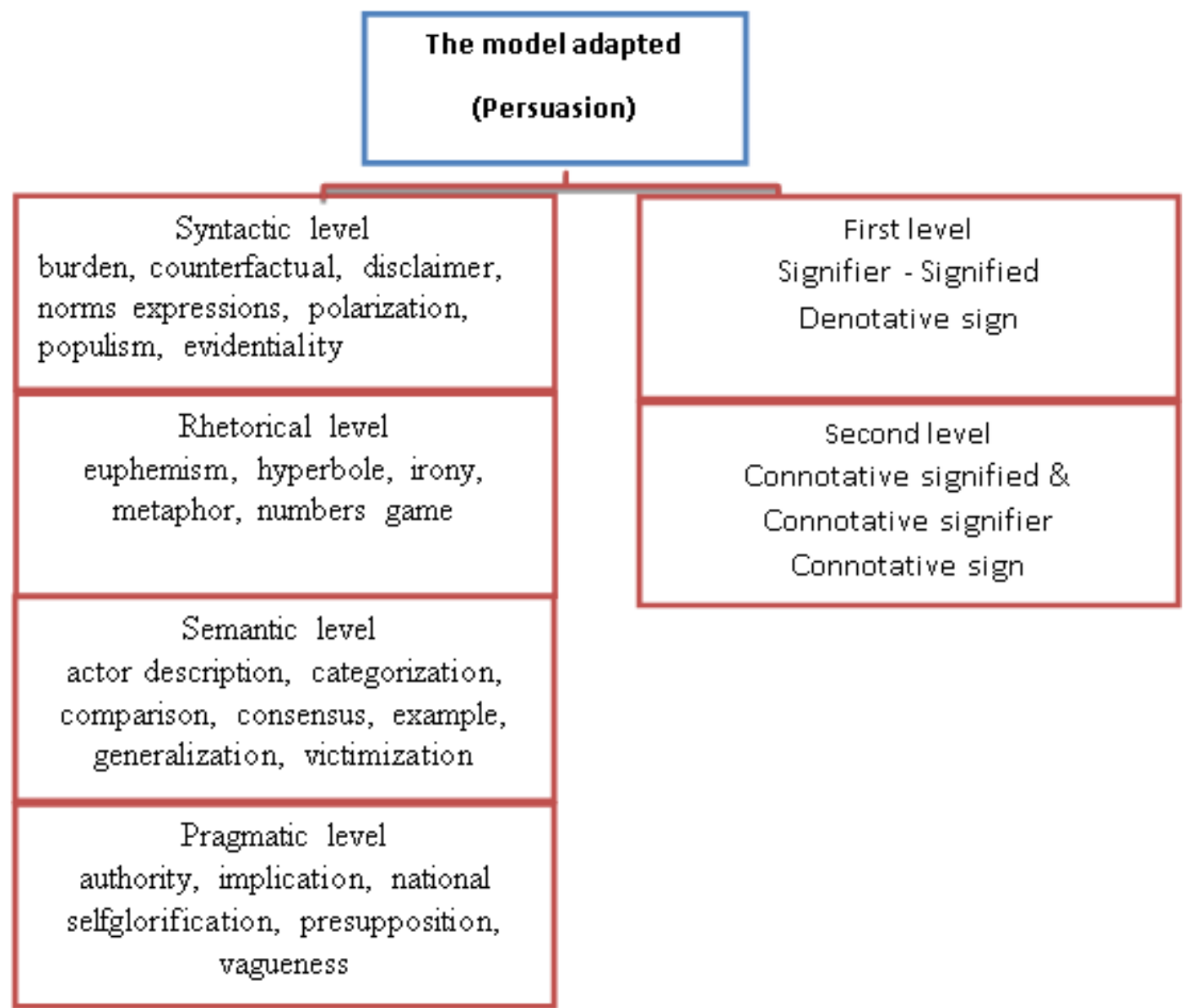

\section{Data analysis}

This section deals with the analysis of the political speeches as far as persuasion is concerned. The analysis will be divided into two sections. The first section deals with the American political speeches and the second section deals with the Arabic political speeches. For each section, two political speeches will be analyzed .

\subsection{American political speeches Analysis}

This section deals with the analysis of American political speeches. The analysis as follows:

\section{First Speech}

\section{"Donald Trump's speech on national security in Philadelphia" 9 /7/ 2016}

The political speech is based on the use of many strategies in order to persuade the recipient. The first strategies that Trump uses in a political dialogue in Philadelphia is the strategy of evidentiality, where he represents himself at the top of the official status in America and as the supreme authority to clarify the important points in his political speech. Basically, his speech is about peace through strength that the use of the pronoun "I" is a clear reference to the authority of the head of state on the grounds that he represents the entire country "I am here to talk about three crucial words that should be at the center of our foreign policy: Peace Through Strength". 
Trump uses another strategy, which is national glorification to focus on the government's achievements during his presidency, which is to increase benefits and develop peace and security, as well as issuing other strategies that secure USA. At the same time, Trump uses the comparison strategy, where he compares his government's achievements with previous policies that led to a failure in the country's management "advancing America's core national interests, promoting regional stability, and producing ...this will require rethinking the failed policies of the past".

Trump, in his political speech in Philadelphia, uses another strategy, which is the authority. With such a strategy, he uses the pronoun 'we' to refer to the whole United States as having the ability to create a safe and stable world without any conflicts. This explains the ideology that Trump follows in order to persuade voters or recipients to clarify that America is capable of everything, and it is the first in the world "We can make new friends, rebuild old alliances, and bring new allies into the fold".

Another strategy that Trump uses in his political speech is the actor description, in which he explains that during his presidency he was able to achieve some realism in government and also through which he was able to eliminate the terrorist presence in the Middle East. This type of event and description represents a kind of American policy that Trump follows in Pointing out that his policy is a successful policy and has a major role in persuading the recipient to agree to Trump's actions "In a Trump Administration, our actions in the Middle East will be tempered by realism. ... power vacuums that are filled by terrorists".

Another appropriate strategy to achieve persuasion is the normal description of the events. It means to describe the events in a real way concerning the goals achieved by the policy such as making peace with other countries and eliminating terrorism. This gives a positive impression of Trump's policy "form new friendships and partnerships based on this mission. We now have an Administration, and a former Secretary of State, who refuse ...terrorism".

Through the strategy of the agreement, Trump clarifies in his political speech that he runs the best country in the world, and this includes another strategy, which is the comparison. Convince the recipient about his successful policy "I will proudly promote our system of government and our way of life as the best in the world". These linguistic phrases are prepared with high accuracy in order to achieve one goal, which is persuasion, where the promoted person manages to make others agree with him.

Sometimes, the speaker uses certain strategies in order to exaggerate a certain action. Such a thing can be done by using words such greatly, scarcely, and many others to achieve a hyperbolic effect. At the same time, Trump uses vagueness strategy in order to give hidden information so that he will achieve a certain goal. All of such strategies are used on purpose in order to achieve persuasion.

\section{Second Speech}

\section{"Trump's final remarks as president" 20 / 1 / 2021}

Trump uses multiple strategies since the beginning of their speech, where he uses the strategy of ambiguity and hyperbole in order to influence the mind of the recipient, and this is clear through the phrases he uses in his speech. He describes his 
deeds as "been an incredible four years. We've accomplished so much together" to show that his government has done a lot to the USA throughout four years. This has an impact on the mind of the recipient because of Trump's words. Trump wanted to make it clear through his speech that his government had done its best to provide the best services to the American people, and this was done through the use of intentionally chosen language in order to persuade the audience that Trump's policy is the successful policy in governance.

Another strategy that Trump follows in his speech is the strategy of actor description, where Trump describes his wife as the first lady in America, who enjoys a very wonderful beauty "our first lady has been a woman of great grace and beauty and dignity", and this has a great role in spreading the reputation among people "so popular with the people". This description shows a kind of close emotional relationship between Trump and his wife as evidence of lining up in the American leadership, where Trump considers his wife as supportive and helpful in order to support him to provide the best for the American people. Such a thing has an impact on the hearers from the emotional side, as it makes people sympathize with Trump in order to convince them about Trump's success in leading the American power. Such actions are intentionally done in order to directly influence the mind of the recipient, and these expressions have a great impact in terms of persuasion

In addition, Trump uses the strategy of self- glorification by mentioning the achievements of his government, as he made it clear that he reconstructed the US army and supported the US Air Force, in addition to other administrative achievements for the American people "created a new force called Space Force that, in itself, would be a major achievement for a regular administration, we were not a regular administration". He shows that his administration was not an ordinary one. It was special. Such a thing leads people to agree with him which results finally in achieving the intended goal. It is simply to get people persuaded of the USA administration.

Trump uses another strategy, which is the metaphor strategy, where he compares the American economy and the increase in it as if it were a missile, in which he explains that the increase that took place in the American economy during Trump's rule has increased at a rocket speed than it was previously "I'm looking at elements of our economy that are set to be a rocket ship up. It's a rocket ship up", which was in a tragic situation and a dilapidated economy.

By referring to the American economy, where Trump uses the counterfactual strategy, in which it is clarified that the increase that took place in the American economy is great because of the policy followed by Trump, which led to a significant increase in the American economy. Thus, he indicates it to be "We have the greatest country in the world" the strongest economy in the world.

Another strategy is the implication strategy. Trump uses this strategy in his political speech in order to describe the American economy in the previous ruling period as a global epidemic "as bad as the pandemic was" that affected all countries of the world and from which countries have become suffering to a great degree. Such a thing is compared to the ruling period of Trump which is a great achievement he did 
during his reign in order to influence the opinion of the electorate and persuade them to elect him again.

\subsection{American Semiotic Analysis}

Two photos are chosen to be analyzed to highlight the political point of view. The first one is chosen from https://www.nytimes.com/ and the second one is from https://www.washingtonpost.com/. The analysis is below:

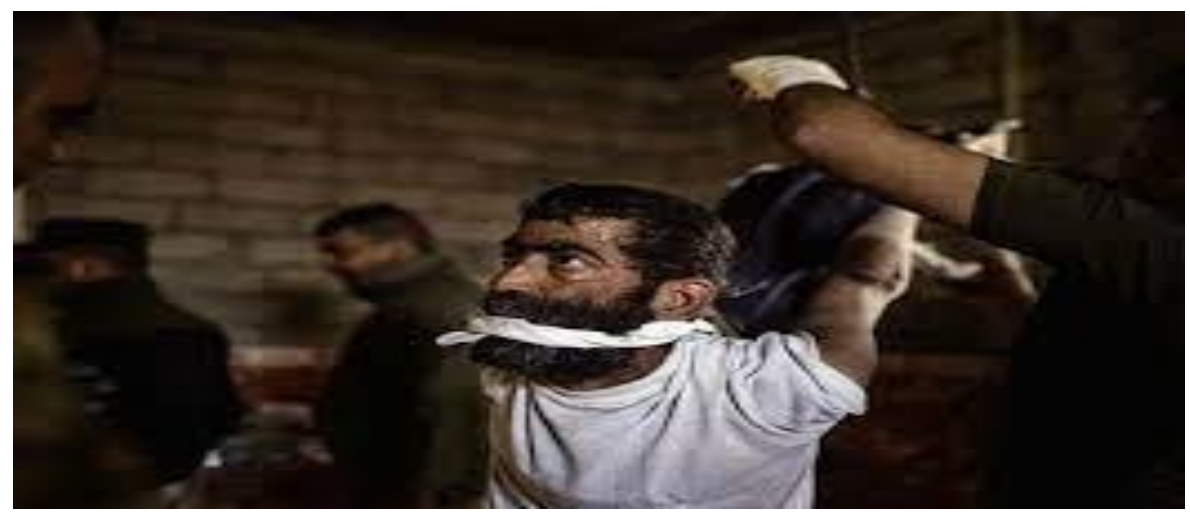

On the denotative level in picture (1), it depicts a notable white man being apprehended by a man: the man standing next to the camera has his hands tied behind his back and his mouth is also covered with a cloth. He is dressed in white. The second man stands along the wall, staring down at the floor. The wall's bricks are exposed, and the setting is surrounded by darkness.

On the connotative level, the photographer takes the picture horizontally to show the misery of the inmates, who are all innocent citizens. The photo's depict the inhumane treatment of Sunni people by Iraqi military. The picture was posted to draw the viewer's attention to them before moving on to the rest of the scene. Both of the detainee's hands are tied to the back of his head, which is close to the cameraman. This is a form of torture in which the victim is unable to prevent his body from being beaten. The man's mouth is likewise sealed with a cloth that appears to have been stolen from his clothing. Closing the mouth in this manner shows that the victim is being severely tormented, and his mouth is securely bound with a towel to prevent him from yelling. Such a thing persuades people that Iraqi troops torture civilians severely.

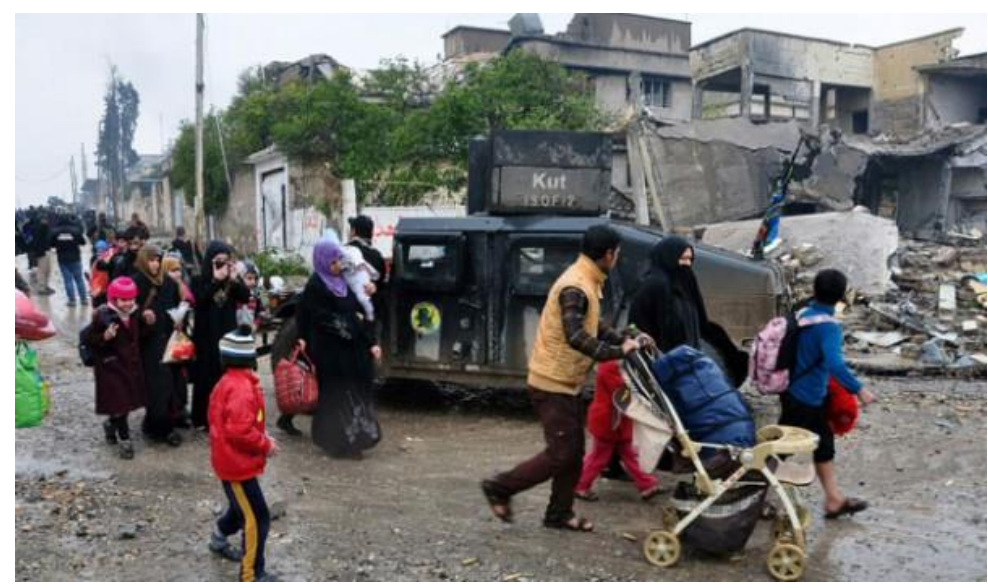

On the denotative level, Mosul, notably the Old City, is depicted in photograph (2). The photo shows the wreckage of the structures as well as the destructed house that 
is still a little bit standing. There are additional many persons in the photo, all of them are women and children. Army cars are still found there stopping beside the smashed house.

On the connotative level, the photographer took the picture from a nearly horizontal position, implying sympathy for the innocent people in the picture. The women and children depicted in the scene are civilians fleeing the conflict. They are all looking forward, implying that there is a point of safety that they are attempting to reach in order to save their lives. Women wear the black color, which is connected with grief. Black is a serious color that evokes powerful emotions, as well as a color that is regarded unappealing and connected with evil. The adolescents in the photograph represent innocence as well as a subject of fragility, powerlessness, and fear, as evidenced by their expressions. Army cars connotes instability.

\subsection{Arabic political speeches Analysis}

This section deals with the analysis of the Arabic political speeches. The analysis as follows:

\section{First speech}

\section{Mr. Mustafa Al-Kazemi During his Inauguration of the Memorial to the Heroes of the Anti-Terror Forces"}

\section{$7 / 9 / 2021$}

The Arabic political speech also depends on a number of strategies used by the speakers. The first strategy used by Mustafa Al-Kazemi in his political speech is the counterfactual as it explains the reason for establishing this memorial is in order to recall the epics and battles of the Iraqi soldiers in the anti-terrorist forces who rose up with all their ferocity to defending their country. This memorial is a tribute and loyalty

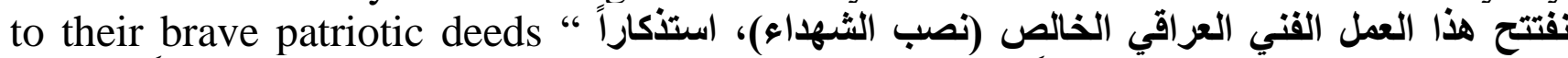

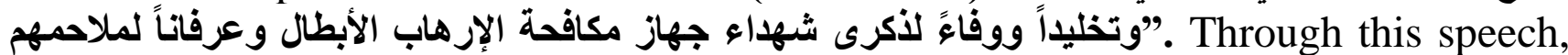
Mustafa Al-Kazemi explains that the Iraqi forces represent the main support of the ingroup against the terrorists who represent the out- group. This description is in order to convey the personal ideology of the speaker in order to influence the mind of the hearers.

Mustafa Al-Kazemi uses another strategy, which is national glorification, through which he records the extent of pride in the Iraqi forces as a source for peace

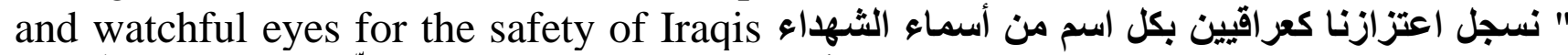
الأبطال، الذين لولا تضحياتهم ما كنّا لنقف هذه الوققة هنا" Such a thing reinforces the idea of the government's support for the security forces in order to convey the idea that a government is practicing continuous functional work through coordination between the security units and the senior leadership. The sacrifices of the security forces are a major reason for the existence of the Iraqi government. If here were no security forces, Iraq would be dented.

There is another strategy used in the political discourse, which is the burden through which Mustafa Al-Kazemi explains in his speech that the terrorist threat to Iraq has affected the Iraqi government causing in inconvenience , since terrorism is 


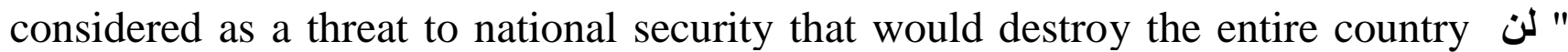
نفض أعينتا، ولن ننام قريري الأعين حنى القضاء على آخر إرهابي في العراق" For this reason, AlKazemi shows that the Iraqi government will remain vigilant in order to eliminate all terrorist detachments in Iraq. This thing gives a positive message to the Iraqi people in order to persuade them that there is a strong government capable of eliminating all security threats represented by the out-group terrorist.

In the end, Mustafa Al-Kazemi uses in his speech the implication strategy through which he sends a message of reassurance to the Iraqi people that the Iraqi " وائنوا، فإن كuch a thing has a great effect on the people's conviction that the speaker is the highest authority in the state and has a great role in the ideology and power that affects the people.

The use of certain linguistic expressions has a great influence on government policy and the quality of political speech, as Mustafa Al-Kazemi uses some words such as "that has an emotional effect in order to attract the attention of the listeners and thus he can deliver the desired message, which is the power of the government and the control of the security forces. This gives a positive impression about the Iraqi politics.

\section{Second Speech}

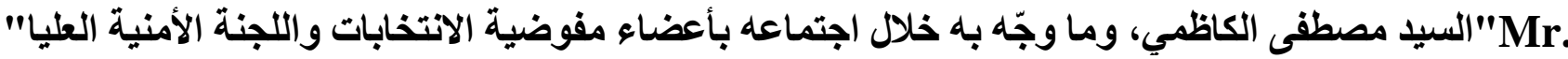 Mustafa Al-Kazemi, and his directions when meeting members of the Electoral Commission and the Supreme Security Committee"1 / 9 / 2021}

Mustafa Al-Kazemi begins his political speech using the strategy of hyperbole, through which he demonstrates the extent of the danger of the next stage represented by holding the elections at an early date, and that this task requires great and "نجتمع بكم اليوم وقبل أسبوع على المهمة الاستثنائية المكلفين بها، والمتمثلة exceptional efforts He uses intentional linguistic terms that have a great impact on the members of the electoral commission in order to clarify the difficulty of the next stage. This is one of the ways of persuasion that Iraqi politicians used to achieve a certain thing.

In order to clarify the transparency of the electoral process, Mustafa Al-Kazemi uses the strategy of national glorification, through which he demonstrates the extent to which the Iraqi people depend on the Electoral Commission to hold fair elections without any corruption, and that this thing will result in a well-established "العراق كله يعوّل على إصراركم المؤكد بشأن ضمان نزاهة العملية الانتخابية، والحفاظ على government "أمنها. For this reason, he explains that this Iraqi committee is a starting point towards bright future, which is the future that Iraqi people hope to obtain.

One of the strategies that Mustafa Al-Kazemi uses in his political speech is the strategy of the victimization, as he makes it clear that the Iraqi people have become

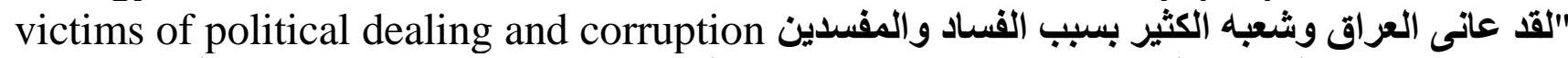
والتزوير بكل عملية انتخابية، وقد حان الوقت كي يزدادوا ثقانة بدولتهم عبر صناديق اقتراع مؤمّنة، وبعيدة عن "أيدي المزورين. It was the result of manipulation in the operations conducted by the electoral commission, which resulted in an opaque government that violated the 
standards of humanity. Electoral deception is one of the main reasons for the destruction of the country, so the speaker uses another strategy, which is implication, through which he indirectly demonstrates the extent of the Iraqis' confidence in the members of the electoral process and the extent to which they dream of having fair elections.

Mustafa Al-Kazemi uses another strategy, which is the strategy of presupposition, where he explains that by participating in the elections, this will result in a government that fulfills the desires of the Iraqi people. Therefore, he describes the elections in that they are historical and fateful, and they represent a starting point towards a future that is different from what it was previously in the previous "مهمتكم اليوم تأريخية، ويإمكانها تغيير مصير بلا، ورفع الحيف والظلم الذي عاثده منذ النظام البائد، regime "This change depends on something very important, which is active participation in the elections. Mustafa Al-Kazemi explains here, through the ideology of the individual mixed with linguistic vocabulary, that the Iraqi people are the ingroup that will defeat the out- group by participating in the elections.

There are other strategies used in the political speech, including the strategy of evidentiality, where Mustafa Al-Kazemi explains that through his government and official status, the Iraqi people are urged to actively participate in the upcoming elections and that this thing will change the situation for the better. For this, it represents a kind of realistic depiction of the events through which it aims to build trust between the people and the government, and this idea is reinforced by Mustafa AlKazemi using another strategy, which is the strategy of actor description, where he uses the name of Mr Al - Sistani. This context creates in the listener's mind a kind of conviction that the prime minister's words are correct, and thus the desired goals will be achieved.

The strategy of the authority is also used in political speech, where Mustafa AlKazemi explains that the security forces represent a legal authority that must take a major role in securing electoral work, and that this must be characterized by impartiality and must not be influenced by any other party. Its primary function is to "على القوات الأمنية تفعيل الجهدين الأمني والمي "و الاستخباري، ومنع التأثير من قبل أي جهة على الناخبين" Such a statement that is considered as a clear announcement about the importance of the elections that Mustafa Al-Kazemi emphasizes in order to secure children and the future of Iraq in general, and this is something that is achieved through the use of some vocabulary items that has a great role in persuading the hearers.

\section{4. Arabic Semiotic Analysis}

Two photos are chosen from Arabic newspapers to be analyzed to show the persuasive political point of view. The first one is chosen from https://asharq.com/ and the second one is from http://alhayat.com. The analysis is below: 


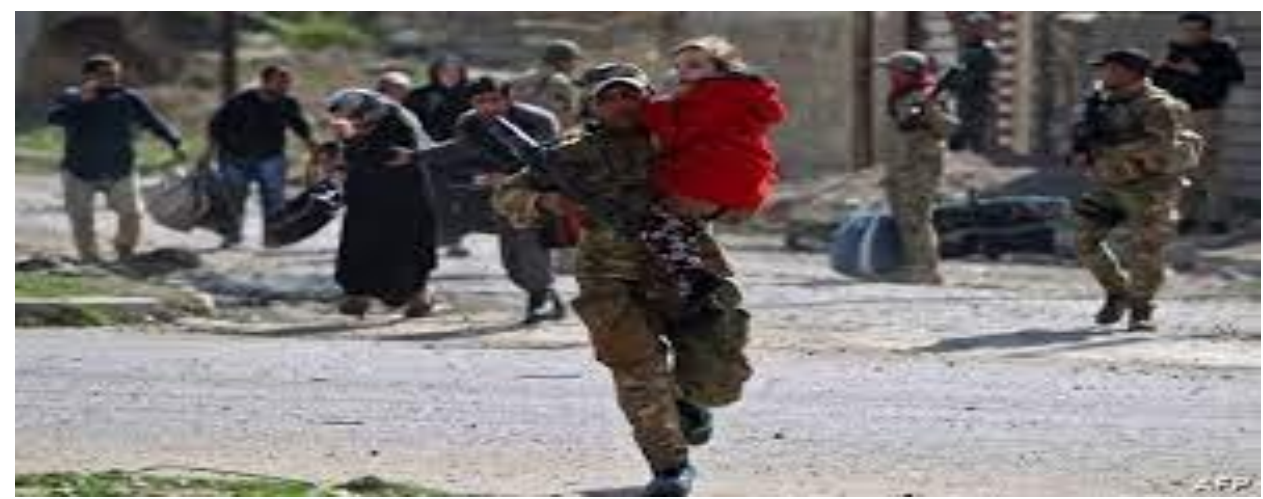

On the denotative level in this photograph ( 1 ), it was captured or taken in one of Mosul's streets for an Iraqi Federal Police officer. Due to his weakness, the police officer is carrying a toddler who is wearing red jacket. There appear to be some frightened pedestrians on the route. The police officer's firearm, which he wears on his hand, is ready to fire. There is a lot of precaution on the street in the photo.

On the connotative level, the photographer uses a horizontal viewpoint to emphasize the fighters' bravery, as well as to persuade the viewer that the military's purpose is to defend civilians. A child is being carried by the federal cop in the photo. This implies that the police officer has shifted his focus from fighting to rescuing civilians. The officer looks away from the camera and toward the horizon, implying that he is requesting assistance from his comrades to save the injured boy and transport him to a safe location. The police officer places his firearm on his hand, signaling that his combat role is still on and that his humanitarian mission to save civilians has begun. The child's clothes are red, and he is weary and frightened. This expresses the extent of the sorrow and suffering endured by Mosul's residents.

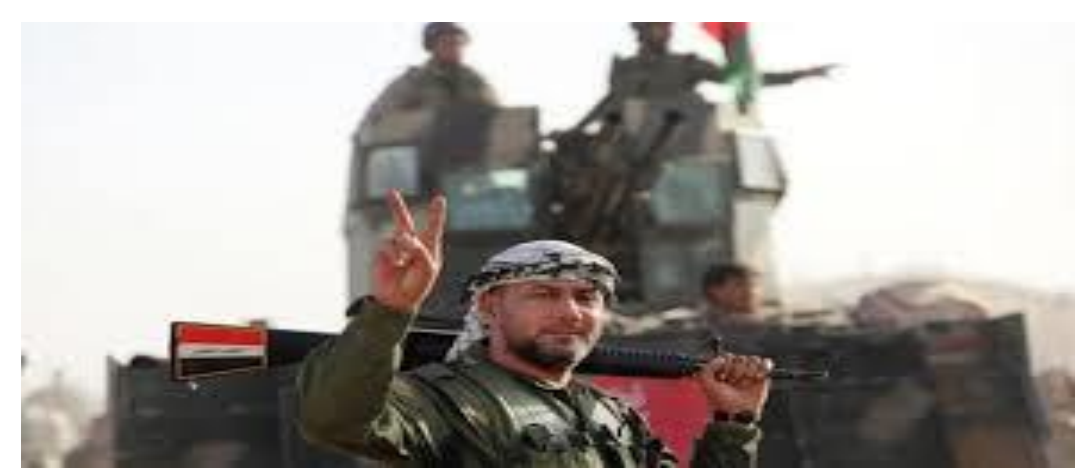

On the denotative level, the picture (2) was taken in western Iraq. A group of PM forces troops stand over military vehicles. They make a hand gesture in front of the camera. Above the military trucks, a swarm of flags rises. Some of the PM's members present cover their heads with cloth to give the impression that they have won.

On the connotative level, the photo was taken from the bottom up, giving the appearance of authority, supremacy, and control to the viewer. Four members of the Prime Minister's Cabinet, who are seated on the tank though one was standing in the foreground of the photograph, raise their hands and point their fingers in the shape of a (V) to persuade Iraqi people of achieving triumph over terrorism. Some of the men on the tank wear helmets to protect head or face from the harsh sunshine, which is likely a 
symbol of rural dominance. The shadows of the automobiles printed on the ground, as well as the dust flying from beneath the wheels, indicate a dry environment.

\section{Results}

The number of the strategies used in each political speech has a very important role in persuading the public. This can be illustrated in the following :

\begin{tabular}{|c|c|c|c|}
\hline $\begin{array}{l}\text { American Speech } \\
1\end{array}$ & $\begin{array}{l}\text { American } \\
\text { Speech } 2\end{array}$ & Arabic Speech 1 & Arabic Speech 2 \\
\hline 1. Evidentiality & 1. Ambiguity & 1. counterfactual & 1. Hyperbole \\
\hline $\begin{array}{l}\text { 2. National } \\
\text { glorification }\end{array}$ & 2. Hyperbole & 2. Burden & $\begin{array}{l}\text { 2. National } \\
\text { glorification }\end{array}$ \\
\hline 3. Comparison & $\begin{array}{l}\text { 3. Actor } \\
\text { description }\end{array}$ & 3. Implication & 3. Victimization \\
\hline 4. Authority & $\begin{array}{l}\text { 4. Self- } \\
\text { glorification }\end{array}$ & & 4. Implication \\
\hline $\begin{array}{l}\text { 5. Actor } \\
\text { description }\end{array}$ & 5. Metaphor & & 5. Presupposition \\
\hline $\begin{array}{l}\text { 6. Normal } \\
\text { description }\end{array}$ & $\begin{array}{l}6 . \\
\text { Counterfactual }\end{array}$ & & 6. Evidentiality \\
\hline 7. Comparison 2 & 7. Implication & & 7. Authority \\
\hline 8. Vagueness & 8. Comparison & & \\
\hline
\end{tabular}

Throughout this classification, it can be clear that the American political speeches have more dominant role in persuading people than the Arabic ones. Such a fact is realized when focusing on the number of the linguistic strategies that are used the political speeches. The American politicians tend to use more strategies for the purpose of persuading people about something. The Arabic political speeches have a persuading effect, but in a limited way. Such a thing will affect badly on people's response towards politicians' speeches. Thus, The American speech will look more persuading to the hearers than the Arabic ones.

Moreover, on the level of semiotics, it is clear that the photos provide the viewers with a larger perspective on the issue. The ideology adopted by media organizations, including political speeches, is to select the appropriate photo that appeals to readers, allowing politicians to achieve their objectives. The American newspapers New York Times and Washington Post published images in this study that attempted to portray a poor image of the Iraqi crisis by utilizing photos of Iraqi military torturing civilians. The images give the impression that security officers are not doing their job of protecting citizens, but rather arresting and torturing them. The public 
mobilization forces are also depicted as illegal militias whose allegiance is to foreign powers. The focus of most of the photographs published in American newspapers is on the destruction of cities as a result of the scale of military engagements, making readers to blame security forces and popular mobilization groups for the destruction.

Arabic newspapers, on the other hand, have a more positive approach to the Iraqi problem. The positive connotation contained in those photos clearly depicts the humanitarian role in helping civilians and releasing them from the control of ISIS. Iraqi military will save civilians from ISIS, according to the show. Such a thing persuades people of the Iraqi army' beneficial role in the country.

\section{Conclusion}

Persuasive strategies are used in both American and Arabic political speeches to elicit emotional responses from the audience and to share the speaker's point of view or notions. When it comes to the usage of the linguistics strategies, it's worth noting that both of the American and Arabic political speeches employ a wide variety of strategies, some of which are reciprocal. They could all be indicating a similar way of thinking about persuasion. Most of the strategies used are (actor description, authority, burden, comparison, consensus, euphemism, evidentiality, counterfactual, illustration, hyperbole, implication, and victimization). Though other strategies are used, but they are not as common as those in parentheses. It has been discovered through data analysis that Arabic political speeches have less techniques than American ones. This is an attempt to express the concept without distorting the truth or inserting irrelevant references.

Both of the American and Arabic political speeches focus of the bad things that happened before their ruling period as a case of focusing on the out-group bad actions, with total emphasis on the in-group actions of their government. In can be seen that the American political speech is more dominant because of using more and more linguistic strategies as one means to achieve persuasion.

So, though political speech is subjective, but it represents a country in itself. It depends on the extent to which one uses discourse strategies to persuade others. If it is done correctly, one can do a miracle. Such a thing can be achieved verbally and visually by focusing on the in-group good deeds and the out-group bad deeds. 


\section{References}

Barthes, R . (1977). Image-Music-Text. London: Fontana.

Batstone, R. (1995). Grammar in discourse: Attitude and deniability. In G. Cook and B.

Blommaert, J. (2005). Discourse: A Critical introduction. Cambridge: Cambridge University Press.

Brown, G. \& Yule, G. (1983).Discourse analysis. Cambridge: Cambridge University Press.

Dahl, R. (1957)."The concept of power". behavioural science. 2.3: 201-2014.

Dewing, M. (2012). Social media: an introduction. Ottawa: Library of Parliament.

Eagleton, T. (1994). Ideology. London: Longman.

Fairclough, N. (1989). Language and power. London: Longman.

Fischer, Andreas( 1994). (ed.). Repetition. Tübingen: Gunten Narr .

Fowler, R. (1991). Language in the news. London: Routledge.

Gumperz, J. (1982). Discourse strategies. London: Cambridge University Press.

Howarth, D. (2000). Discourse. Buckingham: Open University Press.

Mills , S.( 1997). Discourse .London: Routledge .

O'keeffe, A.(2006). Investigating media discourse. London and New York. Routledge.

Osborn, M. \& Osborn, S.( 1988). Public speaking. Boston: Houghton Mifflin Company.

Schwarzmantel, J. (2008). Ideology and politics (2nd ed.). London: Sage Publications.

Stubbs, M. (1983). Discourse analysis. Oxford: Blackwell.

Van Dijk (2006c). "Discourse and manipulation". In Discourse and Society. Vol. 17, No.2: 359-83. London: Sage. https://pdfs.semanticscholar.org. [Accessed in 6 May,2017]. 